\title{
Micro-Finance for Women Empowerment: A Rural-Urban Analysis
}

\author{
M Saiful Islam ${ }^{1}$, Tarikul Islam² \\ ${ }^{1}$ Economics and Finance Department, College of Business Administration, University of Hail, KSA \\ ${ }^{2}$ Economics Department, Kalaroa Government College, Satkhira, Bangladesh \\ saifecon@yahoo.com
}

\begin{abstract}
This paper examined the micro-finance services towards empowerment of unprivileged women in the southwestern part of Bangladesh. A sample of 300 low profile unprivileged micro-finance service receiving women equally from rural and urban areas of Khulna district were surveyed during May, 2018. Data were collected on the usage and effectiveness of micro-finance services and were analyzed using STATA 12. Multiple regression model and descriptive statistics were used to interpret data. Economic empowerment, social empowerment, interpersonal empowerment and political empowerment were considered to measure women empowerment. The study found that proper use of microcredit, marital status of women, educational status of women and their husbands, personal income and their position in the family were the main determinants of women empowerment. Women empowerment score remained higher in urban areas than in rural areas. The availability of micro-finance services improved the status of unprivileged low profile suburban women in terms of income generation, saving mobilization, the creation of household assets and overall poverty reduction of rural women. Thus, microfinance has been a useful tool for women empowerment and economic development in both areas but more effective in urban areas.
\end{abstract}

Keywords: Micro-finance, Unprivileged Women, Economic Empowerment, Social Empowerment, Interpersonal Empowerment, Political Empowerment.

\section{Introduction}

Women empowerment is a vital issue for any developing country like Bangladesh, because they are an integral part of the society, but their participation in economic activities as well as their status and decision making a role in social activities remains very negligible. Throughout the developing world women's status in general remains vulnerable that calls for their empowerment. Bangladesh being one of the least developed countries and predominantly rural based, women enjoy less power and freedom in society, and therefore remain vulnerable. Bangladesh has a population of 142.3 million, among which 50 percent are female (GOB, 2011). At the national level there exists 31.5 percent poverty, while at the rural area it is 35.2 percent and 21.2 percent in urban area (GOB, 2010). Of this total population, women are particularly vulnerable, as they financially depend on the male section of the society. Economic development is not possible for keeping this huge segment of society vulnerable. Micro-finance is a crucial tool to provide access to finance to this vulnerable group, and empower them to ensure economic development of the country. Micro-finance institution mainly targets women to cater to economic development and assists to empower them.

It assists women attaining control over the means to make a living. It is about women lifting themselves out of poverty and vulnerability. It enhances women acquiring economic and political empowerment within their homes, their village and their countries (Micro Credit Summit, 2000). Women empowerment is the process to attain the ability from which those who have been unable to make the strategic choices of life. Women empowerment augments the economic growth of the family and reduction in poverty in a developing country (Klasen, 1999). Women who are economically solvent have a positive role in household decision making with high bargaining power to boost spending on education and health (DFID, 2007). There is straightforward and direct link between access to micro-finance and raising the status of women within their households and societies: it is believed that micro-finance increase empowers of women (Hunt and Kasynathan, 2002). Empowerment is a person's capability set (Sen, 1993). The 'capability of an individual relies on different indicators involving individual characteristics and social arrangements. Empowerment is the ability to fulfill this ability and not just the choice to do so. Sen's opinion on women empowerment indicates that the focus should be on certain universally valued functioning which transmits to the basic fundamentals of survival and well-being. These involve proper nourishment, good health and shelter (Sen, 1990). 
Women empowerment is the process of internal change (Mayoux, 1998) and the ability to make right decisions on the family and society and take ownership of their lives through spreading of their choice (Kabeer, 2001). Women are an equally important human resource as men, as half of the population of the country is female, and so without their participation the nation-building activities are not possible. Therefore, empowering women is crucially important for socio-economic development. This paper aims at analyzing women empowerment through the use of micro-finance in urban-rural comparative setup and is organized in four sections. Section 1 deals with introduction and objectives of the study and literature review, section 2 describes the methodology, section 3 highlights the empirical results and discussions, and finally section 4 concludes the paper with policy recommendations.

\section{Literature Review}

Armful researches are surfaced on micro-finance and women empowerment. These studies show that microfinance admittance to women develops nutrition level and increase hope for children's education in the household (Panjaitan-Drioadisuryo and Cloud, 1999), enhance consumption expenditure of household (Pitt and Khandker, 1996) and contributes to the reduction of household poverty (Chowdhury et al., 2005). Several studies find that there is a positive relationship between microcredit and women empowerment (Khan et al., 2011; Simanowitz and Walker, 2002 and Lalitha and Nagarajan, 2002). Fayyaz (2002) considered three indicators such as economic, social and political indicators to measure women empowerment. Kumar and Sreedhara (2004) considered another three categories such as economic, social and general empowerment. Noreen (2011) described that working women assist to formulate national income of the country and contribute to a sustainable livelihood of the families and communities throughout the world. The study found that the empowerment status of rural women in Bahawalpur city of Pakistan can be significantly developed by enhancing their income generating activities by imparting loan without any collateral through different micro-finance programs. Regression result showed that age, education of husband, marital status, number of sons, father property and loan amount are influential factors rather than many other factors.

Asim (2008) found the impact of micro-finance on indicators of women empowerment in the urban centre of Lahore district in Pakistan. This study considered indicators involving economic decisions, social mobility decision, child and health-related decisions, resource allocation decision and autonomy based indicators involving household purchase decision. To investigate the relationship between women empowerment and micro-credit participants the study took three different estimates such as simple parametric framework of conditional mean dependence, randomization of treatment and bivariate probit model. The result showed that micro-credit program was insignificant in explaining all the outcome indicators of empowerment for the sampled household. Women empowerment is a multidimensional concept because it is determined by many socio-economic factors and cultural values. For measuring women empowerment, it took four indices in making a cumulative index. The results stated that married women and women having Islamic view have a statistically positive impact on women empowerment (Chaudhury and Nosheen, 2009). Husain (1998) reported that women's micro-finance involvement with BRAC acts as a change in lessening women economic dependence on their husbands and other male kin.

With the independent source of income, women don't rely solely on their husbands for purchasing personal and household items. Relationship with husbands improved because of providing capital for investment. Begum and Biswas (1998) found that education, women's income and employment had a positive impact on decision making the power of women. Participation of women in income generating activities of government and nongovernment organization increases women's decision making power. Goetz and Gupta (1994) revealed that women's empowerment only be achieved by increasing women's consciousness about gender and class relation and organizing them to engage in gross roots struggles for women's rights. Rahman et al. (2002) revealed that when women earn money, they have a more prominent role in family decision making with respect to the expenditure of income and other related family matters. This active participation by women may assist to improve their personality as well as help the family by making it possible to take more judicious decisions. Participation of women in credit programs of rural development organization (Grameen Bank and BRAC) enhanced the mobility, their capacity to buy and participate in major household decisions, their ownership of productive assets, their political and legal awareness and participation in public campaigns and protests. 
Thus, women empowerment could be achieved through the involvement in various income generating activities as well as productive employment (Hashemi et al., 1996). Women empowerment is measured by various kinds of power such as economic, social, political and interpersonal powers. Economic power involves access to income, markets, assets, food and decision making power in economic activities. Social indicators include entrance of certain bases of individual indicators as education, age, marital status, family size and position in the family in social organization. Political power involves a decision on own future that affects future activities. Interpersonal power includes a person's sense of potency which is dependent on selfconfident behavior and self-esteem (Friedman, 1992). Khan et al. (2011) studied the impact of microcredit scheme of Punjab Rural Support Program (PRSP) on women empowerment. This study compared the status of women before taking microcredit and after taking it. Microcredit program increased awareness of women and women's empowerment. It raised involvement in the children education, self-identity, literacy level, visiting shopping and participating in family budgeting. Malik and Luqman (2005) revealed that microfinance raised the economic status of women. It assisted women to earn extra income through which they can earn significantly greater financial autonomy.

Zaman (2001) depicted that microcredit reduced the vulnerability of the poor by the creation of an asset, increasing income and consumption, provision of emergency support and empowering emboldening women by imparting them control over property and enhanced self-esteem and knowledge. From the discussion above it appears that women empowerment depends on different kinds of factors such as economic, social, political, and interpersonal factors. Women empowerment reduces the poverty level of the household, increasing the decision power of women in the household, enhancing income, increasing participation in the social and cultural organization, increasing self-sufficiency and self-esteem. Most of the researches conducted on women empowerment through micro-finance in Bangladesh are based on rural areas; very few studies investigated the urban areas. To best of the knowledge, there is also a literature gap on women empowerment through micro-finance in rural-urban comparison setup in Bangladesh. This study aims to bridge this gap up and link the study of micro-finance in women empowerment in the rural-urban context in a comparative manner.

\section{Methodology and Study Area}

This study was based on a primary survey, which was held in the south-west region of Bangladesh. This region has twelve districts namely- Khulna, Satkhira, Bagerhat, Jessore, Narial, Magura, Meherpur, Jhenaidaha, Khustia, Chuadanga, Rajbari and Faridpur. The sampling was designed following a purposive and multistage sampling technique. To select the study area, only Khulna district (10 percent) was conveniently selected. Khulna City Corporation (KCC) was selected as the urban area, where out of 31 wards in KCC, 3 wards (10 percent) namely Rupsha, Tutpara and South Tutparawards were selected. In the rural segment, Khulna district has 9 upazilas, out of which Batiaghata (10 percent) upazilawas conveniently selected. From Batighataupazila, we conveniently selected 6 villages namely, Jalma, Baliadanga, Kismoth Khulna, Hoglabunia, Tetultola, and Chokrakhali. A sample of 300 household respondents were randomly surveyed, 150 respondents from an urban area and another 150 respondents from a rural area. Theses households took micro-finance services from different MFIs namely Grameen Bank, BRAC, ASA, TMSS, JCF, SUS and Agrogati working in the region. An interview schedule containing both closed and open-ended questions was used as the research instrument to collect relevant information from the respondents of the selected urban and rural areas. Both qualitative and quantitative techniques were used for data collection. Numerical data has been quantitatively analyzed, while socio-political variables are qualitatively analyzed. STATA 12 and MS Excel 2010 were used to analyze data.

Dimensions of Women Empowerment: Women empowerment is measured from four different dimensions, e. g economic, social, interpersonal and political empowerment.

Dependent Variables of the Study: Women empowerment remains the only dependent variable. However, as four dimensions of women empowerment, e.g., economic, social, interpersonal and political empowerment were considered, we considered four separate dependent variables, each is translated by a set of explanatory variables. According to the above method we first formed economic empowerment index, social 
empowerment index, personal empowerment index and political empowerment index and run with dataset but the result was not satisfactory at all.

Table 1: Description of Dependent Variables

Name of Dependent Variables

Women Empowerment

$\begin{array}{ll}\text { Economic empowerment } & \text { Index } \\ \text { Social empowerment } & \text { Index } \\ \text { Interpersonal empowerment } & \text { Index } \\ \text { Political empowerment } & \text { Index }\end{array}$

Parveen and Leonhäuser (2005) calculated the dependent variables by Cumulative Empowerment Index (CEI) which was constructed by combining some key empowerment indicators like women contribution to household income, access to resources, ownership of assets, participation in household decision-making, perception on gender awareness, coping capacity to household shocks, access to the political activities etc. to get a complete idea of women empowerment. Each indicator again has a number of sub-indicators. The quantitative part corresponded to five categories e.g., Very low $=1$, Low $=2$, Average $=3$, High $=4$ and Very high=5.Each indicator assigned a quantitative rank from 1 to 5 according to the total score for each empowerment indicator received from its sub-indicators based on the field survey. The qualitative dimension was formed to rank of the key indicators. Then, we determine the dependent variables by applying the Bartlett method.

Bartlett Method: This method of averaging reduces the variance, compared to the original $\mathrm{N}$ point data segment. We collect the dataset of women empowerment by the Likert scale and determine the simple averages and apply data normality test like Cronbach alpha, and Kaiser-Meyer-Olikin (KMO) tests. Then we apply the Bartlett method of averaging.

Measurement Items: Likert scale value of 1 to 5 (Very low =1, Low=2, Average $=3$, High=4 and Very high=5).

Table 2: Cronbach Alpha, Rabidity Coefficient

\begin{tabular}{ll}
\hline Cornbrash's alpha & Internal Consistency \\
\hline$\alpha \geq 0.9$ & Excellent \\
$0.9>\alpha \geq 0.8$ & Good \\
$0.8>\alpha \geq 0.7$ & Acceptable \\
$0.7>\alpha \geq 0.6$ & Questionable \\
$0.6>\alpha \geq 0.5$ & Poor \\
$0.5>\alpha$ & Unacceptable \\
\hline
\end{tabular}

Kaiser-Meyer-Oilskin (KMO) Test: KMO is the test for sampling adequacy. It is a measure of how suited the data is for factor analysis. The test shows sampling adequacy for each variable in the model. It is the proportion of variance among variables. The lower the proportion, the more the dataset is suited to factor analysis.

Table 3: Rule of Thumb for KMO Test

\begin{tabular}{ll}
\hline KMO Value & Degree of Fitness \\
\hline 0.00 to 0.49 & Unacceptable \\
0.50 to 0.59 & Poor \\
0.60 to 0.69 & Questionable \\
0.70 to 0.79 & Acceptable \\
0.80 to 0.89 & Good \\
0.90 to 1.00 & Excellent \\
\hline
\end{tabular}


Explanatory Variables of the Study: The explanatory variables used in this study are demographic factors, social factors, economic factors and micro-finance indicator. Table 4 describes variable categories, their name and unit of measurement.

\section{Table 4: Description of Explanatory Variables}

\begin{tabular}{lll}
\hline Variable Category & Name of Explanatory Variable & Unit of Measurement \\
\hline Demographic Factor & Location & 0=Urban, 1=Rural \\
Social Factors & Age of the respondent & Number of years \\
& Education & Year of schooling \\
& Household Size & Number of family members \\
& Marital status of women & $0=$ unmarried, 1=married \\
& Position in the family & Number \\
Economic Factors & Earning members & Number of wage earners \\
& Working hour & Working hour per day \\
& Income & BDT per month \\
Micro-finance Indicators & Expenditure & BDT per month \\
\hline
\end{tabular}

Source: Author's Compilation, 2018

Regression Model for Measuring Women Empowerment: Women empowerment depends on various factors as depicted in Table 2.1. To determine the impact those factors on women empowerment, four multiple regression models have been formulated. According to our country's situation and condition of the study area following models have been formed for identifying which factors influence women empowerment.

$W E=\beta_{0}+B_{i} X_{i}+\mu_{i}$

Where,

$W E=$ Women empowerent: economic empowerment, social empowerment, personal empowerment, and political empowerment.

$X_{i}=$ Set of explanatory variables

$\mu_{i}=$ Error term

$\beta_{0}$ and $B_{i}$ is the coefficients.

\section{Results and Discussion}

The micro-finance institutions (MFIs) caters loan to the poor people especially to the less privileged women. The MFIs go to the doorsteps of the people, and people need not go to the MFIs. The other vital characteristics of micro-finance are: collateral free, small size, minimum paperwork, demands driven, 95 percent women borrowers, over 90 percent loan recovery rate, workers make regular visits to the borrower's yard to advise and supervise and lastly loans are returned in instalments on the weekly or bi-weekly basis. More or less all the NGOs follow the above-mentioned characteristics to conduct the micro-finance program in Bangladesh (Islam, et al. 2010 cited by Islam and Reza, 2011).

Descriptive Statistics of Women Empowerment: Descriptive statistics are used to summaries the sample data. The basic interpersonal data of the respondents related to the women empowerment are presented in the following Table 5. 
Table 5: Descriptive Statistics

\begin{tabular}{llll}
\hline Aspects & Category & Urban & Rural \\
\hline Year of Schooling & No Education & 2 & 2 \\
& Primary & 48 & 37 \\
High School & College & 77 & 93 \\
& Higher Studies & 19 & 12 \\
Total $=$ & 4 & 6 \\
Marital Status & Married & $\mathbf{1 5 0}$ & $\mathbf{1 5 0}$ \\
& Single & 134 & 134 \\
& Widow & 0 & 2 \\
Occupation & Divorced & 9 & 9 \\
& Total $=$ & 7 & 5 \\
& Housewife & $\mathbf{1 5 0}$ & $\mathbf{1 5 0}$ \\
& Business & 113 & 122 \\
& Labor & 11 & 4 \\
& Tailor & 11 & 10 \\
& Teacher & 14 & 9 \\
& Total $=$ & 1 & 5 \\
& Agriculture & $\mathbf{1 5 0}$ & $\mathbf{1 5 0}$ \\
& Service & 40 & 66 \\
Type of Micro-finance service & Business & 23 & 25 \\
& Other & 46 & 40 \\
& Total = & 41 & 19 \\
& Group loan & $\mathbf{1 5 0}$ & $\mathbf{1 5 0}$ \\
& Individual loan & 1 & 5 \\
& Cash loan & 6 & 3 \\
& In-kind loan & 142 & 141 \\
& Total = & 1 & $\mathbf{1 5 0}$ \\
\hline Samily Income & 150 &
\end{tabular}

Source: Author's calculation based on field survey data

It is evident that the overall most of the respondents are literate both in the urban and rural areas. Most of the women studied up to high-school level in both areas, some of them completed higher studies too. Thus, it provides a sound image of women's education which is crucial for women empowerment. The marital status of the respondent women is almost similar in both the areas. There is no considerable difference between urban and rural areas with reference to the marital status of the women. Occupation is an important determinant to women empowerment. It is found that 113 and 122 respondents were engaged to household activities in urban and rural areas respectively. The remaining women were more or less engaged in business, teaching and selling labor to the service sector. Source of family income also determines the empowerment level. Agriculture remained the key sector of family earnings to rural women, followed by agro-business and services. On the other hand, the urban women were almost equally engaged in agro-business, agriculture, business and other activities such as a warehouse, factory mill, ship breaking, and saw-mills. Type of microfinance services revealed that almost exclusively cash loans were provided both in urban and rural areas, and in very few cases individual loans, followed by group loans were advanced. A micro-finance service is the key indicators of women empowerment and poverty reduction that is practiced throughout the rural and suburban area of Bangladesh since the last few decades. Sometimes it brings a positive result and sometimes not, but it is widely accepted and practiced all over the world especially third world countries.

Inferential Statistics of Women Empowerment: Based on a sample dataset, the regression analyses produced the following results. 
Table 6: Results of Regression Analysis

\begin{tabular}{|c|c|c|c|c|}
\hline Explanatory variables & Economic & Social & Personal & Political \\
\hline \multirow{2}{*}{$\begin{array}{l}\text { Location(0=urban, } \\
1=\text { rural) }\end{array}$} & $-0.019 * * *$ & $-0.0256^{*}$ & $-0.0387^{* *}$ & 0.0290 \\
\hline & $(0.0064)$ & $(0.0135)$ & $(0.0152)$ & $(0.0234)$ \\
\hline \multirow[t]{2}{*}{ Age } & 0.000916 & $0.00297^{*}$ & $0.00388^{* * *}$ & -0.00259 \\
\hline & $(0.00151)$ & $(0.00176)$ & $(0.00140)$ & $(0.00216)$ \\
\hline \multirow[t]{2}{*}{ Year of schooling } & $0.604^{*}$ & -0.00316 & $0.00651^{* *}$ & -0.00678 \\
\hline & $(0.325)$ & $(0.00393)$ & $(0.00313)$ & $(0.00483)$ \\
\hline Marital & $0.0688^{*}$ & 0.00680 & 0.00685 & 0.0241 \\
\hline \multirow[t]{2}{*}{$\begin{array}{l}(0=\text { unmarried, } \\
\text { married })\end{array}$} & & & & \\
\hline & $(0.023)$ & $(0.0290)$ & $(0.0230)$ & $(0.0356)$ \\
\hline \multirow[t]{2}{*}{ Household size } & $0.0987^{* *}$ & $0.0661^{* * *}$ & $0.0533^{* * *}$ & $0.101^{* * *}$ \\
\hline & $(0.048)$ & $(0.0248)$ & $(0.0197)$ & $(0.0304)$ \\
\hline \multirow[t]{2}{*}{ Position in the family } & $0.0488^{* *}$ & 0.0617 & 0.0275 & -0.00857 \\
\hline & $(0.0212)$ & $(0.0703)$ & $(0.0558)$ & $(0.0862)$ \\
\hline \multirow{2}{*}{$\begin{array}{l}\text { Number of earning } \\
\text { members }\end{array}$} & $0.146^{* *}$ & $0.0412^{*}$ & 0.0207 & 0.0432 \\
\hline & $(0.0602)$ & $(0.0231)$ & $(0.0184)$ & $(0.0284)$ \\
\hline \multirow[t]{2}{*}{ Working hours } & -0.00707 & $-0.00855^{* * *}$ & 0.00180 & $-0.00696^{* * *}$ \\
\hline & $(0.0198)$ & $(0.00166)$ & $(0.00132)$ & (0.00203) \\
\hline \multirow[t]{2}{*}{ Income } & $0.0003^{* * *}$ & $2.25 \mathrm{e}-06$ & $4.56 \mathrm{e}-06^{* * *}$ & $9.84 \mathrm{e}-07$ \\
\hline & $(0.00142)$ & $(1.77 \mathrm{e}-06)$ & $(1.40 \mathrm{e}-06)$ & $(2.17 \mathrm{e}-06)$ \\
\hline \multirow[t]{2}{*}{ Expenditure } & $3.07 \mathrm{e}-06^{* *}$ & $-6.88 e-07$ & $1.24 \mathrm{e}-06$ & $-1.30 e-06$ \\
\hline & $(1.51 \mathrm{e}-06)$ & $(1.74 \mathrm{e}-06)$ & $(1.38 \mathrm{e}-06)$ & $(2.13 e-06)$ \\
\hline \multirow[t]{2}{*}{ Micro-finance service } & $7.60 \mathrm{E}-04^{* * *}$ & $6.60 \mathrm{e}-08$ & $-1.27 \mathrm{e}-06^{* * *}$ & $1.10 \mathrm{e}-06^{* *}$ \\
\hline & $-2.00 \mathrm{E}-04$ & (4.08e-07) & (3.24e-07) & (5.00e-07) \\
\hline \multirow[t]{2}{*}{ Constant } & $72.74^{* * *}$ & $0.612^{* * *}$ & -0.0722 & $0.575^{* * *}$ \\
\hline & $(9.644)$ & (0.117) & $(0.0928)$ & $(0.143)$ \\
\hline Total observations & 300 & 300 & 300 & 300 \\
\hline R-squared & 0.28 & 0.19 & 0.27 & 0.16 \\
\hline
\end{tabular}

Source: Author's calculation based on data from field survey, 2018

Note: Standard errors in parentheses, ${ }^{*}=$ significant at 10 percent level, ${ }^{* *}=$ significant at 5 percent level, ${ }^{* * *}$ $=$ significant at 1 percent level.

The value of r-squared although not high is acceptable. The variations in women empowerment are explained by the variations in the explanatory variables used in the four models. It is found that urban women are more empowered than the rural women people in case of economic, personal and social empowerment. The result is statistically significant at 1 percent, 5 percent and 10 percent level of significance respectively. Age and education are also important factors for empowering women. It is found that age has a positive influence on personal and social empowerment of the women. The result is statistically significant at 1 percent and 10 percent level respectively. Similarly, the education level of women has a positive impact on personal and economic empowerment, as educated women are more aware of their rights. The result is significant at 5 percent and 10 percent level of significance respectively. The marital status also played an important role in empowering women. The married women were more economically empowered than the unmarried women, as an unmarried woman depends on the father's income as well as they get less opportunity to engage in economic activity. The result is significant at 10 percent level.

It is evident that family size empowers women positively. The bigger the family size, the higher is the earning potentials, and the lesser is the pressure on the family. The result is significant at 1 and 1 percent level of significance. Women's position in the family has a positive impact on economic empowerment, as a senior woman can easily engage in economic activity. The result is significant at 10 percent level. It is also evident that earning members have more economic and social empowerment. The result is significant at 5 percent and 10 percent level respectively. It is found that women's larger working hour dampens their social as well 
as political empowerment, as longer working hours restrict them to spare time for sociopolitical activities. The result is significant at 1 percent level. It is evident that greater personal income empowers the women both economically and personally, and the result is statistically significant at 1 percent level. This is obvious because an increase in personal income empowers them to utilize money independently without depending on other family members. Similarly, it is seen that expenditure makes them economically empowered, the result is statistically significant at 5 percent level. This is might be because they can independently spend for their own purchases without any family interference.

\section{Conclusion}

It is found that micro-finance services made the women empowered economically and politically. This is because micro-finance services enable them to take decision independently. The result is statistically significant at 1 and 5 percent level. However, it makes them personally vulnerable when the borrowed money needs to be returned with interest. The result is statistically significant at 1 percent level. The foregoing discussion reveals that micro-finance services have been an effective tool for overall women empowerment in both areas urban as well as rural areas. It positively influences women's socioeconomic and political affairs. The influential factors of women empowerment were a proper use of microfinance, education and marital status of women, education status husbands, family size and number of earning members, age and position of women within the family, working hour, income, and expenditure.However, there is some gap in empowerment between urban and rural areas as women in urban areas are more conscious about their rights than in rural area.Therefore, MFIs while extending micro-finance services, should provide proper training, and monitor the credit recipients' activities to ensure proper utilization of borrowed fund. This will eventually reduce poverty and magnify the standard of living of the unprivileged rural women.

\section{References}

Asim, S. A. (2008). Evaluating the Impact of Microcredit on Women's Empowerment in Pakistan. CREB Working Paper, 2-9.

Begum, S. A. \& Biswas, T.K. (1998). Women's Empowerment and Fertility, Comilla: Bangladesh Academy for Rural Development (BARD).

Chaudhury. \& Nosheen. (2009). The determinant of Women Empowerment in Southern Punjab, Pakistan: An Empirical Analysis. European Journal of Social Science, 10(2).

Chowdhury, M. J. A., Ghosh, D. \& Wright, R. E. (2005). The Impact of Micro-credit on Poverty: Evidence from Bangladesh. Progress in Development Studies, 5(4), 1-12.

DFID. (2007). Gender Equality Action Plan 2007-2009 Making Faster Progress to Gender Equality. A DFID Practice Paper, UK.

Fayyaz, A. (2002). Successful Community Development: Pakistan. Asian Productivity Organization, 267-284.

Friedmann, J. (1992). Empowerment: The Politics of Alternative Development, U.K.: Blackwell Publishers, Oxford.

GOB. (2010). HOUSEHOLD INCOME and EXPENDITURE SURVEY, Bangladesh Bureau of Statistics, Statistics Division, Ministry of Planning.

GOB. (2011). POPULATION and HOUSING CENSUS, Bangladesh Bureau of Statistics, Statistics Division, Ministry of Planning.

Goetz, A. M. \& Gupta, R. (1994). Who Takes the Credit? Gender, Power and Control over Loan Use in Rural Program in Bangladesh. Unpublished Manuscript. Brighton, UK: Institute of Development Studies, University of Sussex.

Hashemi, S. M., Schuler, S. R. \& Riley, A.P. (1996). Rural Credit Programs and Women's Empowerment in Bangladesh. World Development, 24(4), 635-653.

Hunt, J. \& Kasynathan, N. (2002). Reflections on Micro-finance and Women's Empowerment. Development Bulletin, 57, 71-75.

Husain, A. M. (1998). Poverty Alleviation and Empowerment -The Second Impact Assessment Study of BRAC's Rural Study Program. Dhaka: Bangladesh Rural Advancement Committee (BRAC).

Islam, M. S. \& Reza, H. (2011). Microcredit's Efficiency and Social Overhead Capital: Go and NGO Coordination.

Kabeer, N. (2001). Conflicts over Credit: Re-evaluating the Empowerment Potential of Loans to Women in Rural Bangladesh. World Development, 29(1), 63-84. 
Kabeer, N. (1998). Money can't Buy Me Love? Revaluating Gender, Credit and Empowerment in Rural Bangladesh. IDS Discussion Paper, 363.

Khan, S., Sajid, M. R. \& Rehman, H. U. (2011). Women's Empowerment through Microcredit: A Case Study of District Gujrat, Pakistan. Academic Research International, 1(2), 2223-9553.

Klasen, S. (1999). Does Gender Inequality Reduce Growth and Development? Evidence from Cross-Country Regressions, Policy Research Report on Gender and Development. Working Paper series, 7, Washington, DC: The World Bank.

Kumar, M. A. U. \& Sreedhara, T. N. (2004). From Passive Participation to Effective Leadership: A Study on the Advances in Women leadership in Daksina Kannada, India. Sixth International Conference of International Society for Third Sector Research (ISTR) Ryerson University and York University Toronto, Canada, 11-14, 1-12.

Lalitha, N. \& Nagarajan, B. S. (2002). Self-help Groups in Rural Development. New Delhi Dominant Publishers and Distributors.

Malik, N. H. \& Luqman, M. (2005). Impact of Microcredit on Women Empowerment. Pakistan Journal of Agriculture Science, 42(34), 100-105.

Mayoux, L. (1998). Participatory Learning for Women's Empowerment in Micro-Finance Programmers: Negotiating Complexity, Conflict and Change. IDS Bulletin, 29(4), 39-51.

Micro Credit Summit. (2000). Empowering Women with Micro-Credit. Campaign to Beijing 5 Conference in New York, June 2000.

Noreen, S. (2011). Role of Micro-finance, in Empowerment of Female Population of Bahawalpur District. International Conference on Economics and Finance Research, Singapore: IACSIT Press, 4 (2011).

Panjaitan-Drioadisuryo, R. D. M. \& Cloud, K. (1999). Gender, Self-Employment and Microcredit Programs: An Indonesian Case Study, The Quarterly Review of Economics and Finance, 39(5), 76-79.

Parveen, S. \& Leonhauser, I. U. (2005). Empowerment of Rural Women in Bangladesh: a household level analysis.

Pitt, M. \& Khandker, S. R. (1996). Household and Intra Household Impacts of the Grameen Bank and Similar Targeted Credit Programmers in Bangladesh. World Bank Discussion Paper No. 320. World Bank: Washington D.C.

Rahman, A., Rahman, R. I., Hossain, M. \& Hossain, S. M. (2002). Early Impact of Grameen Bank: A Multidimensional Analysis. Dhaka: Grameen Trust.

Sen, A. K. (1990). Gender and Co-operative Conflict. In: I. Tinker, ed. Persistent inequalities. New Delhi: Oxford University Press, 123-149.

Sen, A. K. (1993). Capability and well-being. In: Nussbaum and Sen, eds. The quality of life. Helsinki: World Institute of Development Economics research.

Simanowitz, A. \& Walker, A. (2002). Ensuring Impact: Reaching the Poorest while Building Financially Self Sufficient Institutions and Showing Improvement in the Lives of the Poorest Women and their Families. Unpublished Background Paper for the Microcredit Summit 5, New York.

Zaman, H. (2001). Assessing the Poverty and Vulnerability Impact of Microcredit in Bangladesh: A Case Study of Bangladesh Rural Advancement Committee (BRAC). Unpublished Background Working Paper for World Bank Development Report. 